\title{
Correction to: Overall survival analysis in patients with metastatic breast cancer and liver or lung metastases treated with eribulin, gemcitabine, or capecitabine
}

\author{
Shayma Kazmi ${ }^{1}$ D $\cdot$ Debanjana Chatterjee ${ }^{2} \cdot$ Dheeraj Raju $^{3} \cdot$ Rob Hauser $^{3} \cdot$ Peter A. Kaufman $^{4}$
}

Published online: 27 April 2021

(c) The Author(s) 2021

\section{Correction to: \\ Breast Cancer Research and Treatment (2020) 184:559-565 \\ https://doi.org/10.1007/s10549-020-05867-0}

In the original publication, two values provided for landmark survival for patients treated with gemcitabine were incorrectly listed in the text. On page 562, paragraph 3 , the text listed that "for TNBC: $50 \%, 31 \%, 20 \%$, and 3\%, respectively, for HR+/HER2-: $51 \%, 27 \%, 10 \%$, and 3\%, respectively". The correct values should be "for TNBC: $50 \%, 31 \%, 11 \%$, and $3 \%$, respectively, for $\mathrm{HR}+/ \mathrm{HER} 2-: 51 \%, 27 \%, 10 \%$, and $7 \%$, respectively". The correct values are consistent with those listed in Table 2.

The original article can be found online at https://doi.org/10.1007/ s10549-020-05867-0.

\section{Shayma Kazmi}

shayma.kazmi@ctca-hope.com

https://www.cancercenter.com

$\triangle$ Peter A. Kaufman

peter.kaufman@uvmhealth.org

1 Cancer Treatment Centers of America, Philadelphia, PA, USA

2 US Health Economics Outcomes Research and Real World Evidence, Eisai Inc., Woodcliff Lake, NJ, USA

3 Cancer Treatment Centers of America Global, Inc., Boca Raton, FL, USA

4 Larner College of Medicine, Division of Hematology/Oncology, University of Vermont Cancer Center, Burlington, VT, USA
Open Access This article is licensed under a Creative Commons Attribution 4.0 International License, which permits use, sharing, adaptation, distribution and reproduction in any medium or format, as long as you give appropriate credit to the original author(s) and the source, provide a link to the Creative Commons licence, and indicate if changes were made. The images or other third party material in this article are included in the article's Creative Commons licence, unless indicated otherwise in a credit line to the material. If material is not included in the article's Creative Commons licence and your intended use is not permitted by statutory regulation or exceeds the permitted use, you will need to obtain permission directly from the copyright holder. To view a copy of this licence, visit http://creativecommons.org/licenses/by/4.0/.

Publisher's Note Springer Nature remains neutral with regard to jurisdictional claims in published maps and institutional affiliations. 